\title{
A brief introduction to the military workplace culture
}

\author{
S.A. Redmond, S.L. Wilcox*, S. Campbell, A. Kim, K. Finney, K. Barr and A.M. Hassan \\ Center for Innovation and Research on Veterans \& Military Families (CIR), School of Social Work, University of \\ Southern California, Los Angeles, CA, USA
}

Received 3 July 2013

Accepted 23 September 2014

\begin{abstract}
.
BACKGROUND: Military culture and workplace are areas of interest for researchers across disciplines. However, few publications on military culture exist.

OBJECTIVE: The purpose of this article is to introduce general concepts regarding the structure and culture of the United States Military and discuss how this creates challenges for reintegrating into the civilian world.

METHOD: Topics that will be covered in this article include an overview of the Department of Defense (DoD) and Department of Veterans Affairs (VA), socialization to military culture, the unique features of the military as a workplace, the cultural experiences of military personnel reintegrating back into the community, and the challenges faced by military members and their spouses.

RESULTS: The provided information on military culture will expand military cultural competency so that civilian employers can enhance their ability to create supportive workplaces for veterans and military spouses during times of transition and reintegration. DISCUSSION: The unique characteristics of the military culture should be understood by those who work with or plan to work with military populations.
\end{abstract}

Keywords: Department of Defense, military personnel, military spouses, military roles, reintegration

\section{Introduction}

The United States (U.S.) military workplace is a unique environment that causes military personnel and families to have experiences that differ from civilians. Military personnel and families are confronted with psychosocial challenges created by an intense work environment, but they demonstrate resilience [1]. To further promote this resilience, researchers and clinicians should understand military culture so they can better interact with veterans in a culturally competent man-

${ }^{*}$ Corresponding author: Sherrie Wilcox, Center for Innovation and Research on Veterans \& Military Families (CIR), School of Social Work, University of Southern California, 1150 S. Olive Street, Suite 1400, Los Angeles, CA 90015, USA. E-mail: SLWilcox@ USC.edu. ner and provide information that will aid in creating supportive working environments [2,3]. Thus, knowing how military service affects military personnel, families, and veterans is key.

Since military culture is largely unique and defined by its organizational structure, framework, and rules, this article focuses on these aspects of military culture and their effect on reintegration following military separation. This article outlines the U.S. Military Departments, features of the U.S. military as a workplace, socialization to the military, and challenges transitioning and reintegrating back into the community. However, purely knowing information about military culture is insufficient for achieving military cultural competency. Cultural competency is typically not reached by learning a single factor (i.e., knowledge) about the group of interest [4]. Therefore, this article aims to expand the knowledge of military culture in those working with 
military populations and bring them closer to achieving cultural competency.

\section{Department of Defense, Military Departments, and Department of Veterans Affairs}

\subsection{Department of Defense (DoD)}

The DoD, with its Pentagon headquarters, is the organizing body in charge of the Military Departments and headed by the Secretary of Defense, who serves as the President's main advisor on defense policy [5, 6]. It is comprised of four major bodies, each with a different leader: (a) Chairman and Vice Chairman of the Joint Chiefs of Staff, (b) Unified Combatant Commands, (c) Office of the Secretary of Defense, and (d) Military Departments. Each Military Department's secretary is accountable to the Secretary of Defense and the Chairman of the Joint Chiefs of Staff is responsible for giving the intended commanders orders from the Secretary of Defense or President [5]. Thus, the DoD operates efficiently and cohesively by delegating tasks while still maintaining interconnectivity between its divisions.

\subsection{The Military Departments}

The Military Departments, which are part of the DoD, consist of five armed forces: Air Force, Army, Marine Corps, Navy, and Coast Guard (housed within the Department of Homeland Security, but assigned to the DoD during war/deployment). Each branch has active and reserve components with active duty military personnel serving full-time and reserve and guard members typically serving part-time. Due to differences in organization and purpose, each of the armed forces has its own subculture. Table 1 presents a description of the mission and core values of each branch, which has a different purpose, mission, and methods of engagement.

\subsection{Department of Veterans Affairs (VA)}

The VA, separate from the DoD, is a highly structured department focusing primarily on veterans. It consists of three main divisions: the Veterans Benefits Administration, providing every VA benefit (e.g., education, compensation, and guaranty for home loan); the Veterans Health Administration, responsible for services pertaining to health care; and the National Ceme- tery Administration, in charge of cemeteries, markers, headstones, as well as "Presidential Memorial Certificates" [7]. Those potentially eligible for VA benefits include: veterans, reservists, National Guard members, and those related to veterans, such as dependents or a "surviving spouse" [7]. However, to qualify, the military member must demonstrate continuous service for either 24 months or the complete amount of time ordered for active duty individuals. Veterans cannot have a dishonorable separation, and National Guard or reserve members must not have been active duty as a result of training purposes alone [8]. Exceptions allow those injured during active duty service to obtain benefits. However, not all who served will receive benefits and veterans must prove an injury is service related to receive benefits.

\section{Characteristics of the military workplace: Diversity in experiences serving}

Both the characteristics of the individual and the military structure itself contribute to military culture. Culture is a product of the social environment and includes a shared sense of values, norms, ideas, symbols, and meanings [9]. It distinguishes groups of people from another and people within cultures often share common ways of seeing the world [9]. However, every person's culture is comprised of a fusion between his or her different boundaries, such as professional, organizational, and national, and this cultural mixing appears in the social identity [10]. Furthermore, culture is ever evolving with different ways of being analyzed [9]. Differentiation perspective focuses on the subcultures within the group, fragmentation perspective stresses the contradictory and ambiguous nature of culture, and integration perspective focuses on the larger cultural themes in collectivistic compared to individualistic manner [9].

Military culture literature often focuses on integration perspective [11]. This perspective provides a framework for understanding how the military uses organization and training to minimize individual differences. However, personal differences remain between enlistees, as jobs and experiences are impacted by gender, sexual orientation, social class, race and ethnicity, and age [12]. This article discusses major themes in military culture, but also in line with differentiation perspective, examines specific military cultural subgroups, including guardsmen, reservists, military spouses, and wounded warriors. 
Table 1

Overview of military departments

\begin{tabular}{|c|c|c|c|c|}
\hline Branch & Founded & Service members & Mission & Core values \\
\hline Army & June 14,1775 & Soldiers & $\begin{array}{l}\text { Fight and win our Nation's war by pro- } \\
\text { viding prompt, sustained land domi- } \\
\text { nance across the full range of military } \\
\text { operations and spectrum of conflict in } \\
\text { support of combatant commanders }\end{array}$ & $\begin{array}{l}\text { Loyalty, duty, respect, selfless ser- } \\
\text { vice, honor, integrity, and personal } \\
\text { courage }\end{array}$ \\
\hline Air Force & September 18, 1947 & Airmen & $\begin{array}{l}\text { Fly, fight, and win... in air, space, and } \\
\text { cyberspace }\end{array}$ & $\begin{array}{l}\text { Integrity first, service before self, } \\
\text { and excellence in all we do }\end{array}$ \\
\hline Navy & October 13,1775 & Sailors & $\begin{array}{l}\text { Maintain, train and equip combat- } \\
\text { ready Naval forces capable of winning } \\
\text { wars, deterring aggression and main- } \\
\text { taining freedom of the seas }\end{array}$ & Honor, courage, and commitment \\
\hline Marine Corps & November 10,1775 & Marines & $\begin{array}{l}\text { Train, organize, and equip Marines } \\
\text { for offensive amphibious employment } \\
\text { and as a force in readiness }\end{array}$ & Honor, courage, and commitment \\
\hline Coast Guard & August 4,1790 & Coast Guardsmen & $\begin{array}{l}\text { Safeguard the Nation's maritime inter- } \\
\text { ests }\end{array}$ & $\begin{array}{l}\text { Honor, respect, and devotion to } \\
\text { duty }\end{array}$ \\
\hline
\end{tabular}

\subsection{Military roles and occupations}

Service members' experiences in the military will differ as a result of their career, assigned to them based upon their aptitude/skills and interests. The military is essentially a fully functioning community with doctors, bus drivers, police officers, and cooks, among others, so individuals have a variety of occupational opportunities available to them, many of which have an equivalent in the civilian workplace. However, unlike civilian personnel, the military's principal occupation is war fighting, but individuals differ on the level to which they are involved in direct combat. The large majority of personnel have careers focused on supporting the greater mission and thus, support those preparing, serving, and returning from combat. Determining an individual's job in the military is fairly straightforward, as each military branch has its own system for identifying specific careers.

\subsection{Status of service: Active duty and reserve}

Individuals' military service is affected by whether they serve as active duty or reserve. Active duty service members focus on their military occupational duties full-time, receive many benefits (e.g., health, childcare, and housing) from the military and have the option of living on military instillations. Reserve members have fewer benefits and cannot live on their military installation, even though they may be called to active duty. Reserve members face unique occupational difficulties as reserve members juggle both military and civilian occupations, where active duty service members focus solely on military occupational duties.

The reserve component is comprised of (a) Ready Reserve, (b) Standby Reserve, and (c) Retired Reserve. Those serving in the reserve may be typical part-time paid reservists, active guard and reserve members, or trained individuals participating in the active component part-time. Also part of the reserve are Individual Ready Reserve (IRR) personnel and inactive National Guard (ING) personnel who have completed their military contract, but have inactive time left during which they are not actively serving but can be called back to duty. In addition, individuals not qualified for IRR due to hardship (e.g., physical disability, substance dependence) or those holding a civilian job more important to national security than their former military job also are part of the reserve. Finally, the Retired Reserve, the largest of the Reserve Components, has over 2 million members who are former military personnel under age 60 and have retired from the military and receive retired pay.

\subsection{Demographics}

In terms of individual characteristics, the military is primarily a young, Caucasian, male force, reflected in the following statistics $[13,14]$. Active duty and reserve members are on average 28.6 and 32.1 years of age, respectively. Identifying as a racial minority is observed for less than one third of active duty members and nearly $25 \%$ of reserve members called to deploy. The active duty and reserve forces are $85.5 \%$ and $82 \%$ men, respectively, and approximately $50 \%$ of 
Table 2

Ranks and pay grades across military branches

\begin{tabular}{|c|c|c|c|c|c|}
\hline Pay grade & Army & Navy & Marine Corps & Air Force & Coast Guard \\
\hline \multicolumn{6}{|c|}{ Commissioned Officer } \\
\hline $\mathrm{O} 10$ & General & Admiral & General & General & Admiral \\
\hline O9 & Lieutenant General & Vice Admiral & Lieutenant General & Lieutenant General & Vice Admiral \\
\hline $\mathrm{O} 8$ & Major General & $\begin{array}{l}\text { Rear Admiral } \\
\text { (Upper) }\end{array}$ & Major General & Major General & $\begin{array}{l}\text { Rear Admiral } \\
\text { (Upper) }\end{array}$ \\
\hline O7 & Brigadier General & $\begin{array}{l}\text { Read Admiral } \\
\text { (Lower) }\end{array}$ & Brigadier General & Brigadier General & $\begin{array}{l}\text { Read Admiral } \\
\text { (Lower) }\end{array}$ \\
\hline O6 & Colonel & Captain & Colonel & Colonel & Captain \\
\hline $\mathrm{O} 5$ & Lieutenant Colonel & Commander & Lieutenant Colonel & Lieutenant Colonel & Commander \\
\hline $\mathrm{O} 4$ & Major & $\begin{array}{l}\text { Lieutenant } \\
\text { Commander }\end{array}$ & Major & Major & $\begin{array}{l}\text { Lieutenant } \\
\text { Commander }\end{array}$ \\
\hline $\mathrm{O} 3$ & Captain & Lieutenant & Captain & Captain & Lieutenant \\
\hline $\mathrm{O} 2$ & First Lieutenant & $\begin{array}{l}\text { Lieutenant Junior } \\
\text { Grade }\end{array}$ & First Lieutenant & First Lieutenant & $\begin{array}{l}\text { Lieutenant Junior } \\
\text { Grade }\end{array}$ \\
\hline $\mathrm{O} 1$ & Second Lieutenant & Ensign & Second Lieutenant & Second Lieutenant & Ensign \\
\hline \multicolumn{6}{|c|}{ Warrant Officer } \\
\hline W5 & $\begin{array}{l}\text { Chief Warrant Officer } \\
5\end{array}$ & $\begin{array}{l}\text { Chief Warrant Officer } \\
5\end{array}$ & $\begin{array}{l}\text { Chief Warrant Officer } \\
5\end{array}$ & - & - \\
\hline W4 & $\begin{array}{l}\text { Chief Warrant Officer } \\
4\end{array}$ & $\begin{array}{l}\text { Chief Warrant Officer } \\
4\end{array}$ & $\begin{array}{l}\text { Chief Warrant Officer } \\
4\end{array}$ & - & $\begin{array}{l}\text { Chief Warrant Officer } \\
4\end{array}$ \\
\hline W3 & $\begin{array}{l}\text { Chief Warrant Officer } \\
3\end{array}$ & $\begin{array}{l}\text { Chief Warrant Officer } \\
3\end{array}$ & $\begin{array}{l}\text { Chief Warrant Officer } \\
3\end{array}$ & - & $\begin{array}{l}\text { Chief Warrant Officer } \\
3\end{array}$ \\
\hline W2 & $\begin{array}{l}\text { Chief Warrant Officer } \\
2\end{array}$ & $\begin{array}{l}\text { Chief Warrant Officer } \\
2\end{array}$ & $\begin{array}{l}\text { Chief Warrant Officer } \\
2\end{array}$ & - & $\begin{array}{l}\text { Chief Warrant Officer } \\
2\end{array}$ \\
\hline W1 & Warrant Officer & - & Warrant Officer & & - \\
\hline \multicolumn{6}{|l|}{ Enlisted } \\
\hline E9 & $\begin{array}{l}\text { Sergeant Major OR } \\
\text { Command Sergeant } \\
\text { Major }\end{array}$ & $\begin{array}{l}\text { Master Chief Petty } \\
\text { Officer } \\
\text { Chief Petty Officer }\end{array}$ & $\begin{array}{l}\text { Sergeant Major OR } \\
\text { Master Gunnery } \\
\text { Sergeant }\end{array}$ & $\begin{array}{l}\text { Chief Master Sergeant } \\
\text { OR } \\
\text { First Sergeant }\end{array}$ & $\begin{array}{l}\text { Master Chief Petty } \\
\text { Officer OR Fleet/ } \\
\text { Command Master } \\
\text { Chief Petty Officer }\end{array}$ \\
\hline E8 & $\begin{array}{l}\text { First Sergeant OR } \\
\text { Master Sergeant }\end{array}$ & $\begin{array}{l}\text { Senior Chief Petty } \\
\text { Officer }\end{array}$ & $\begin{array}{l}\text { First Sergeant OR } \\
\text { Master Sergeant }\end{array}$ & $\begin{array}{l}\text { Senior Master } \\
\text { Sergeant OR First } \\
\text { Sergeant }\end{array}$ & $\begin{array}{l}\text { Senior Chief Petty } \\
\text { Officer }\end{array}$ \\
\hline E7 & Sergeant First Class & Chief Petty Officer & Gunnery Sergeant & $\begin{array}{l}\text { Master Sergeant OR } \\
\text { First Sergeant }\end{array}$ & Chief Petty Officer \\
\hline E6 & Staff Sergeant & $\begin{array}{l}\text { Petty Officer First } \\
\text { Class }\end{array}$ & Staff Sergeant & Technical Sergeant & $\begin{array}{l}\text { Petty Officer First } \\
\text { Class }\end{array}$ \\
\hline E5 & Sergeant & $\begin{array}{l}\text { Petty Officer Second } \\
\text { Class }\end{array}$ & Sergeant & Staff Sergeant & $\begin{array}{l}\text { Petty Officer Second } \\
\text { Class }\end{array}$ \\
\hline E4 & $\begin{array}{l}\text { Corporal OR Special- } \\
\text { ist }\end{array}$ & $\begin{array}{l}\text { Petty Officer Third } \\
\text { Class }\end{array}$ & Corporal & Senior Airman & $\begin{array}{l}\text { Petty Officer Third } \\
\text { Class }\end{array}$ \\
\hline E3 & Private First Class & Seaman & Lance Corporal & Airman First Class & Seaman \\
\hline E2 & Private Second Class & Seaman Apprentice & Private First Class & Airman & Seaman Apprentice \\
\hline E1 & Private & Seaman Recruit & Private & Airman Basic & Seaman Recruit \\
\hline
\end{tabular}

Note: The Navy does not use grade W1, the Coast Guard does not use grades W1 or W5, and the Air Force does not have Warrant Officers [13, 14].

both active duty and reserve members are married [13]. These numbers highlight ethnic minorities' and females' unique experiences in the military as underrepresented personnel.

\subsection{Appeal of joining the military and service obligation}

Service members show diversity in their reasons for enlisting, which impacts how they view service.
DoD Youth Polls' data revealed seven themes related to enlisting: fidelity, risk, family, benefits, dignity, challenge, and adventure [15]. Fidelity and dignity emerged as two leading themes [15] and not surprisingly the number of individuals enlisting increased after the September 11, 2001 terrorist attacks [16]. Furthermore, another study [17] identified the following four themes for enlisting: institutional (desire to serve your country, patriotism, and desire for adventure/challenge); future-oriented (desire for a military 
career and money for college); occupational (desire to support one's family, best available option); and pecuniary (ability to repay college loans and receive an enlistment bonus). Those serving for institutional values are more likely to choose the military as a career and believe in service to their country, whereas material incentives are a stronger motivator for others $[15,17,18]$.

Regardless of their reason for joining, individuals sign a lengthy contract specifying their terms of service. The Military Service Obligation requires enlistees to serve a total of at least eight years, unless discharged sooner, for an initial enlistment [19], typically translating into four years active duty and four years in the reserve component for active duty members. However, active duty service is often extended, particularly for those choosing the military as a career.

\subsection{Military ranks: Officer and enlisted}

Service members differ on whether they choose to enlist or accept commission as an officer. Typically, commissioning requires minimally a bachelor's degree, whereas enlistees normally have only a high school diploma or equivalent. On average there is one officer per five enlistees [13]. One's specific duties vary due to their military designation with different expectations for commissioned officers, enlisted and senior enlisted personnel (E-5 and higher; see Table 2) known as non-commissioned officers, and warrant officers (former enlisted members).

\subsection{Military laws, regulations, and chain of command}

One of the more unique features of the military is that military personnel and their family members are bound by military laws, regulations, traditions, norms, and values that differ from civilians. The Uniform Code of Military Justice (UCMJ) outlines military specific laws intended to maintain the requisite level of good order and discipline, conceptualized as the chain of command, which categorizes military service. Good order refers to the rules and laws required to maintain a society that most people are familiar with, while the discipline aspect gives one service member authority over another. Simply put, the chain of command is the hierarchical structure of seniors and subordinates. Senior military personnel must issue lawful orders that junior military personnel must execute. While the concept of senior and subordinate is not unique to the military, authorities granted by law are. For this reason, military personnel must follow lawful orders and directives or violate the law and in doing so commit a criminal act.

However, an important consideration in such orders is the human element, which reflects elements of trust and confidence. The trust and confidence subordinates have for a leader is key for leader legitimacy [20-22]. A subordinate must trust the lawfulness of orders received, support the mission, and be confident that the risk and sacrifice to accomplish the mission is necessary. Likewise a senior must trust their orders will be performed and be confident that all actions will be conducted in a way that keeps good order and discipline. The structure of seniors and subordinates forms a chain with each individual linked to one another. When trust and confidence is weak or broken, the chain is broken to the detriment of good order and discipline.

Both ceremonial acts of discipline, such as shoe shinning, salutes, uniforms, as well as functional discipline where service members follow rules and orders of commanders are deeply embedded within the military culture [9]. Seniority within the military requires obedience and subordinance, with the superior individual responsible for the performance and personal wellbeing of their subordinates. This concept is unique and essential for combat operations.

\subsection{Military ranks and grades}

With great importance placed on the chain of command, the military has a hierarchal rank/grade system (consisting of a letter and number) that indicates position, pay, and authority in the military. Each branch names the various grades differently, and this name indicates the rank (e.g., Sergeant, Staff Sergeant, Captain). This hierarchal system is key to many military cultural aspects and determines who is in charge; even those possessing the same rank/grade have a scaled order. Each ranking encompasses unique expectations, as the military is a coercive hierarchy with elaborate rules, power classification, regulations, and a vertically steep grade [9]. Table 2 presents the ranks and grades across military branches.

\subsection{Differences in culture}

As differentiation perspective illustrates, large differences exist among service members. Those whose military and personal lives greatly overlap are likely to highly prioritize the military mission and values, remaining very much institutionally oriented [9,23]. 
However, those seeing the military as a means-to-anend likely remain oriented to their occupation and focus attention outside the military. While military culture itself is more institutionally oriented, certain military subgroups, including guardsmen, reservists and officers, may tend to be occupationally oriented with members oriented toward civilian careers. Furthermore, cultural dynamics can alter during times of war and peace. During peacetime the military focuses on training and maintenance and boredom is rife, but during wartime the focus is on courage, fear, control, and us vs. them mentality with collective, strong, and cohesive culture being important $[9,23]$.

\section{The military workplace and uniformity between service members' experiences}

\subsection{Basic training}

While all cultures integrate individuals, the military in particular needs a collective, strong and cohesive culture, allowing it to operate functionally during crises. Some service members join the military already identifying with the culture, whereas others develop such an identity following military socialization [9,23]. Therefore, the military socializes new recruits through exhaustive military training known as basic training or boot camp, which is known as a degrading process, where leaders deconstruct the recruits' civilian status and give them a new identity. The recruits go through a harsh, humiliating, and physically and emotionally exhausting process [9,22,23]. They are exposed to their new norms, language, codes, and identity. Also, group formation is accomplished by cutting hair, common dress, suffering, eating, exercising and bunking together, as well as isolation from friends and family since compliance is needed in the military. Leaders emphasize that only the elite make it and encourage recruits to learn to control their emotions. After this training, recruits show greater commitment to the military [9].

\subsection{Warrior ethos}

Another unifying aspect of military culture is the warrior ethos, a mindset and group of values that all U.S. armed forces aim to instill in their members. The warrior ethos emphasizes placing the mission above all else, not accepting defeat, not ever quitting, and not ever leaving behind another American [24]. Un- til 2003, the warrior ethos was an unspoken norm, but in 2003 the Army turned this norm into a codified statement [24]. Although each branch has a unique creed and set of values (e.g., loyalty, commitment, and honor), all branches in the military subscribe to the warrior ethos, even if it is not specifically codified within their branch. Subscribing to the warrior ethos helps set expectations of what it means to be a warrior [25]. Furthermore, instilling this mindset in all service members is crucial for maintaining a highly effective and committed force by encouraging individuals to think and behave in ways that show perseverance; responsibility for others; motivation by a higher calling; and ability to set priorities, make tradeoffs, adapt, and accept dependence on others [25].

\subsection{Military organization, structure, and culture}

Military culture and values extend well beyond the warrior ethos and service members are somewhat isolated from the larger U.S. society [9,23]. The military tries to create uniformity by emphasizing core values that become an integral part of military culture and experience, and service members possess shared experiences, values, languages, and symbols [9,23]. The codes of conduct in the military are the same for every member and expected to be upheld and personal growth happens in an environment that is extremely structured [12]. Nonstop training and selfimprovement, engagement civically and in the community, health, and personal responsibility are all stressed by the military [12]. Obedience, discipline, self-sacrifice, trust, and courage are also identified as key military values [26-29], which demonstrates the importance of looking out for the team's wellbeing above that of the individual [26].

The normative ways of thinking and acting according to military culture become ingrained for active duty members who work and reside on post since those around them are also part of the military $[18,26]$. Also, due to the military's mission and contracts, service members are subject to different workplace regulations than their civilian counterparts; for example, 24-hour a day and 7-day a week call, vacation time can be issued and/or canceled by their commander based on mission needs, and they can be asked to deploy abroad with short notice [9].

However, Howard (2006) argues that reserve forces make up a subculture somewhat different from active duty military culture because they usually work and reside away from bases [26]. Low proportions of U.S. 
citizens have served in the latest conflicts $[26,30]$ and in the same conflicts, more reservists have served and are relaying on civilian communities for support. This exemplifies the challenges individuals face while participating in both civilian and military culture that emphasize different values.

\section{Military culture and the spouse}

The influence of military culture also profoundly impacts military spouses as they become unified within the military context. A military spouse hierarchy often forms based upon the rank of the serving spouse, but some spouses have expressed a desire to be assessed by their personal attributes rather than by their service member's rank, which they perceived as stigmatizing, and other studies have found disapproval of the non-military spouse acting as if the service member's rank is their own rank [31,32]. However, in reality, privileges are given to higher ranking military families, such as enhanced housing facilities [32].

Spousal categorization can either create a sense of community and support for military spouses or it can act as a barrier [32]. Even though first-term military wives benefit emotionally from mentor type relationships with older or more experienced military wives only a minority of first-term wives report such relationships [33]. Military wives are inclined to befriend other military wives whose husbands are similar in ranking to their husband's rank and as differences in rank between military husbands become greater, friendships become less likely to form [33]. It is possible that higher-ranking military wives often think it is too timeconsuming or burdensome to teach a newer military wife about military culture, so they choose to interact with similarly ranked wives. This is consistent with Kurzban and Leary's [34] theory that those belonging to a social species have the critical adaptive issue of deciding to interact with others who probably produce benefits, while staying away from individuals that may prove costly [34].

A husband's ranking may also come with certain social responsibilities for his wife pertaining to military social functions. For example, a military commander unable to attend an event or function, may send his wife on his behalf to show his support and she will receive the respect consistent with his rank [32]. Furthermore, certain activities among military wives are expected based on spousal ranking. For instance, the wife of a battalion commander did not insist that the wives of battalion officers have regular get-togethers and was criticized by a higher ranked brigade commander wife who learned of the issue from a junior wife [32].

Military service also leaves military spouses disproportionately responsible for family demands, especially during deployment. Reservist spouses indicated having to assume their spouse's role while they are away and make decisions related to the family and maintenance of the household [35]. Spouses wonder about the reservists' reaction to their choices, as well as questioning what the choice of the reservist would have been and indicate difficulty assuming added responsibilities and roles [35,36], such as taking care of pets and children by oneself instead of jointly.

\section{Deployment and reintegration}

The most unique features of the military include deploying to locations around the world and being exposed to combat. Returning from combat and deployment often involves transitioning back to the home environment, and in some cases back to the civilian environment, known as reintegration. Reintegration is challenging for some military personnel $[37,38]$, while others return home and experience minimal difficulty [39, 40]. The latter group of individuals may experience some circadian dysrhythmia (e.g., jet lag, which interferes with the sleep cycle) as well as mild environmental disorientation, often due to a change in geographical location. However, other military personnel face much more serious issues upon returning home and some present with debilitating medical and mental health problems requiring treatment $[37,38]$.

Despite the drastic differences in symptom severity, there is no checklist to identify who will have difficulty with reintegration and who will not. However, military personnel with mental health issues prior to deployment will likely return with that same illness and possibly with more severe symptoms, which may become treatment-resistant [38,41-43]. Three prevailing mental health issues include depression (14\% which rises to $27 \%$ after the third deployment), posttraumatic stress disorder (PTSD;14\%), and suicide risk, with veteran males twice as likely to die by suicide compared to civilian counterparts [12]. Traumatic brain injury (TBI) was also found to be fairly common (19\%) [12]. Furthermore, sexual assault was reported by $6.8 \%$ of women and $1.8 \%$ of men (lower than the estimated actual rate of $20-30 \%$ and $2-4 \%$, respectively) [12]. This comes with considerable implications for emo- 
tional wellbeing given that sexual assault carries, at minimum, an equivalent risk for PTSD as exposure to combat carries [12].

Service members' mental health challenges cause great distress for the service member and his or her partner. In more than $70 \%$ of couples where the veteran had PTSD, significant relationship distress was reported, while for couples without PTSD just around $30 \%$ indicated distress $[44,45]$. This is not surprising due to the emotional numbing associated with PTSD that causes emotional withdrawal, less positive engagement, decreased ability to communicate in a validating and effective way, and less intimacy [46]. Furthermore, in an attempt to deal with their experience, veterans may develop attachment that is anxious or avoidant (insecure attachment styles in which one may either overly seek or push away their partner) in response to war trauma [47]. During reintegration, these individuals focus on their safety instead of resuming the relationship in a healthy way, so unhealthy couple interactions, such as one partner being demanding and the other partner withdrawing, might occur [47]. Intimacy issues in couples may also arise due to mental health issues and sexual functioning changes [68]. Problems pertaining to sexual relationships, expression, or the response system have been noted in $60 \%$ of individuals with TBI $[48,62]$. Thus, service members' mental health problems develop into couples' problems.

Research suggests early intervention correlates with positive outcomes and recovery $[39,49,50]$, but seeking treatment may be easier for some service members than others. Once reserve and National Guard personnel are no longer on active orders, access to the same services available to active duty members decreases and their families bear the burden of helping them receive services [36,39,40,50-52]. Thus, changes in benefits put reserve and National Guard personnel at higher risk for more significant reintegration challenges [36,50,52].

\section{Implications for the workplace}

As they exit the military and reintegrate to civilian life, finding employment is a top priority for many veterans. However, frequent moves decrease veterans' opportunities to form and capitalize upon professional relationships or social networking to gain employment [53]. Additionally, veterans often need assistance creating a civilian friendly resume and verbally translating their military service into civilian language [53].
However, because many veterans have little, if any, experience with the civilian workforce, they often underutilize the vast array of transition and employment services available to them [53].

\subsection{Special considerations for reserve \& national guard personnel}

Having fewer available services than active duty members and unique work challenges exacerbates the employment difficulties of reserve and National Guard members. Military service can impede gaining and maintaining civilian employment as reserve and $\mathrm{Na}-$ tional Guard members may experience conflicting military and civilian employment demands. For example, reservist and guardsmen's civilian employment may be disrupted by mandatory monthly trainings and possible 6-18 month deployments, with employment separation and disruption due to deployments linked to economic hardship and emotional stress [54]. Upon returning from deployment, reservist and guardsmen experience employment setbacks, including being laid off; entering into a different, unfamiliar position; passed over career opportunities, outdated expertise; and unemployment $[35,55]$. Specifically, recent research has found an over $40 \%$ increase in unemployment following deployment, while $11.1 \%$ lost their job or business and $15.1 \%$ reported problems with finances [56].

\subsection{Special considerations for military spouses}

Military spouses may also face many employment barriers and have indicated that their spouses' military service negatively affected their work opportunities [57]. Compared to their civilian counterparts, military spouses are twice as likely to be unemployed, more likely to be seeking employment, and even when employed, earn less [55]. One primary factor is that military couples often marry young (e.g., shortly after high school) and frequent relocations and family demands often make completing college or pursuing a steady career difficult. Another barrier for military spouses is that they often have time lapses and location changes indicated in their resumes from frequent moves [57].

Additional challenges associated with the military spouse lifestyle may also make maintaining steady employment difficult. Military spouses can feel like single parents during deployment [57] and one study indicated during deployment, the top stressor for military families is child care issues [58,59]. Heightened 
distress and anxiety levels may be felt by children and spouses, who worry about their loved one's safety and families feel more distress with longer deployment periods [60]. Thus, those whose spouses are absent for longer may need the most support. For those military spouses that are employed, extra support may be needed during deployment and reintegration, as the family faces a highly ambiguous time.

\subsection{Families: Employment, deployment, and reintegration}

Homecoming is stressful for families, as the family system works to reintegrate the service member into the family's routine $[47,60]$. During deployment, spouses adapt by relying on their own problem solving and outside social support, which can make emotionally supporting one another difficult for couples during reintegration [47]. Flexible and understanding work environments can help alleviate some of military spouses' stress during these adjustment periods, as spouses may struggle with personal emotional distress and child behavior problems.

Further complicating reintegration, many veterans return with physical and mental health challenges. Marital relationships temporarily or permanently change as some spouses become caregivers of their wounded service member [61]. The so-called "signature wounds" of the past wars, TBI and PTSD change relationships and have been tied to lower ability to communicate and intimacy, less positive engagement, sexual functioning issues, and higher divorce rates [46, $62,63,68]$. Support for service member and veteran partners is vital for the healthy transitioning of many veterans back into the community. The lack of supportive relationships contributes to mental health challenges [63] with one study finding $75 \%$ of veteran suicides were linked to a failed relationship [61].

Military demands and mental health challenges may also raise the risk of intimate partner violence (IPV) and child maltreatment among military and veteran families. IPV in military families is positively correlated with PTSD, depression, substance abuse, enlisted status, and length of deployment [64]. Additionally, specific factors correlated with increased rates of maltreatment in military families include: young age of child [65], service member leaving for deployment [66], combat-related deployments [67], and service member returning from deployment [66]. During times of deployment and reintegration, military and veteran families would benefit from additional supportive services in the community and workplace, especially when they have young children and their service member returns with physical and/or mental health challenges [67].

\section{Discussion}

The military workplace culture possesses a number of unique features and military personnel experience circumstances that differ from many civilians. While many of the basic concepts are similar to the civilian workplace, the military workplace achieves its goal of creating a mission ready force through socialization, structure, discipline, and constant training. When returning from a deployment marked by separating or discharging from military service, military personnel have the challenge of reintegrating back into the civilian world. After always putting the group's wellbeing first, as well as working and living within the military culture, adapting to civilian culture may be difficult for military personnel. Reserve members might have additional challenges as they navigate the reserve subculture, in addition to living and working amongst the civilian culture, while simultaneously fulfilling work, training, and deployment obligations in the military culture. Employers must also remember that military wives form their own subculture and may need special assistance during their service member's deployment and reintegration, as well as with finding and maintaining employment.

This article provided basic concepts related to the military culture and workplace that those working with military populations should consider. Many companies still appear to be lacking in military cultural competency, which may negatively impact veterans and military spouses seeking employment as well as these individuals' work experiences. For example, employers lacking military cultural competency may pass over job candidates if they fail to appreciate how military skills translate to the civilian sector or interviewers that lack military cultural knowledge may ask job candidates questions about their service that are inappropriate or offensive. Furthermore, employers may misinterpret employees' behavior if they are unaware of military culture, i.e. an employee's reluctance to do anything unless given explicit instructions may be misinterpreted if employers are unaware of the military's emphasis on discipline and following orders passed down through the chain of command. Due to the complexity of military culture, the concepts discussed in 
this article are just the starting point for increasing military cultural competency. However, raising awareness and starting the dialog about military culture appears to be the first step in influencing those working with service members, veterans, and their families to act in a way that is culturally competent.

\section{Conclusions}

Understanding military culture can help those working with service members, veterans, and their families understand this group's unique strengths, skills, and challenges. Having a basic knowledge of military organization reveals certain ingrained values and highlights commonality and diversity between service members' experiences according to the nature of their service. This article was intended to show that military service is not just an occupation, but instills a unique skill set and set of values that in some ways differs from civilians. This article also draws awareness to the possible reintegration difficulties and challenges in the civilian job sector that service members and their spouses may face due to the military experience. As this article has outlined, those working with military service members, spouses, and veterans should acknowledge diversity and avoid sweeping generalizations. We hope this article will serve as a starting point for helping employers working with service members and veterans to increase awareness and their cultural competency.

\section{References}

[1] Saltzman WR, Pynoos RS, Lester P, Layne CM, Beardslee WR. Enhancing family resilience through family narrative coconstruction. Clinical Child and Family Psychology Review. 2013: 1-17.

[2] Yamada A-M, Atuel HR, Weiss EL. Military Culture and Multicultural Diversity among Military Service Members: Implications for Mental Health Providers. Handbook of Multicultural Mental Health: Assessment and Treatment of Diverse Populations. 2013: 389.

[3] Savitsky L, Illingworth M, DuLaney M. Civilian Social Work: Serving the Military and Veteran Populations. Social Work. 2009; 54: 327-39.

[4] Deardorff DK. Identification and assessment of intercultural competence as a student outcome of internationalization. Journal of Studies in International Education. 2006; 10(3): 241-66.

[5] Department of Defense. MIssion Statement 1994 [April 14, 2014]. Available from: http://govinfo.library.unt.edu/npr/ library/status/mission/mdod.htm.

[6] Department of Defense. About the Department of Defense (DOD). Available from: http://www.defense.gov/about/.
[7] Department of Veterans Affairs. Office of Public and Intergovernmental Affairs 2014 [April 14, 2014]. Available from: http://www.va.gov/opa/newtova.asp.

[8] Department of Veterans Affairs. Health Benefits 2014 [April 14, 2014]. Available from: http://www.va.gov/healthbenefits/ apply/veterans.asp.

[9] Soeters JL, Winslow DJ, Weibull A. Military culture. Handbook of the Sociology of the Military: Springer, 2006, pp. 237-54.

[10] Straub D, Loch K, Evaristo R, Karahanna E, Srite M. Toward a theory-based measurement of culture. Human Factors in Information Systems. 2002: 61-82.

[11] Winslow D. Army culture. DTIC Document, 2000.

[12] Kelty R, Kleykamp M, Segal DR. The Military and the Transition to Adulthood. Future of Children. 2010; 20(1): 181-207.

[13] Department of Defense. Demographics 2011: Profile of the Military Community. Washington, DC: Department of Defense; 2012, November.

[14] Department of Defense. Demographics 2010: Profile of the Military Community. Washington, DC: Department of Defense, 2010.

[15] Eighmey J. Why do youth enlist? Armed Forces \& Society. 2006; 32(2): 307-28.

[16] Department of Defense. Personnel \& Procurement Reports and Data Files: Military Personnel Statistics 2012 [May 14, 2012]. Available from: http://siadapp.dmdc.osd.mil/personnel /MILITARY/miltop.htm.

[17] Woodruff T, Kelty R, Segal DR. Propensity to Serve and Motivation to Enlist among American Combat Soldiers. Armed Forces \& Society. 2006; 32(3): 353-66.

[18] Griffith J. Institutional Motives for Serving in the U.S. Army National Guard. Armed Forces \& Society. 2008; 34(2): 23058.

[19] Department of Defense. Enlistment/Reenlistment Document Armed Forces Of The United States. In: Defense Do, editor. Washington, DC: Department of Defense, October 2007.

[20] Kelman HC. A social-psychological model of political legitimacy and its relevance to black and white student protest movements. Psychiatry: Journal for the Study of Interpersonal Processes, 1970.

[21] Olsen ME. Process of social organization, 1968.

[22] Jones AP, James LR, Bruni JR. Perceived leadership behavior and employee confidence in the leader as moderated by job involvement. Journal of Applied Psychology. 1975; 60(1): 146.

[23] Moore BA. Understanding and working within the Military Culture. In: Moore BA, Penk WE, editors. Treating PTSD in Military Personnel: A clinical handbook. New York, NY: The Guilford Press, 2011, pp. 9-22.

[24] Wong L. Leave no man behind: recovering America's fallen warriors. Armed Forces \& Society. 2005; 31(4): 599-622.

[25] Riccio G, Sullivan R, Klein G, Salter M, Kinnison H. Warrior Ethos: Analysis of the concept and initial development of applications. DTIC Document, 2004.

[26] Howard JL. The role of culture in shaping perceptions of discrimination among active duty and reserve forces in the US military. Employee Responsibilities and Rights Journal. 2006; 18(3): 171-87.

[27] Collins JJ. The complex context of American military culture: A practitioner's view. Washington Quarterly. 1998; 21(4): 213-28.

[28] Hillen J. Must US military culture reform? Orbis. 2000; 43(1): 43-57. 
[29] Townshend C. Militarism and modern society. The Wilson Quarterly (1976-). 1993; 17(1): 71-82.

[30] Feaver PD, Kohn RH. Conclusion: The gap and what it means for American national security. Soldiers and civilians: The civil-military gap and American national security. 2001: 45974.

[31] Dandeker C, French C, Birtles C, Wessely S, editors. Deployment Experiences of British Army Wives Before, During and After Deployment: Satisfaction with Military Life and Use of Support Networks. Human Dimensions in Military Operations - Military Leaders' Strategies for Addressing Stress and Psychological Support; 2006; Neuilly-sur-Seine, France.

[32] Harrell MC. Army officers' spouses: Have the white gloves been mothballed? Armed Forces \& Society. 2001; 28(1): 5575.

[33] Rosen LN, Moghadam LZ. Impact of military organization on social support patterns of Army wives. Human Organization. 1989; 48(3): 189-95.

[34] Kurzban R, Leary MR. Evolutionary origins of stigmatization: The functions of social exclusion. Psychological bulletin. 2001; 127(2): 187.

[35] Faber AJ, Willerton E, Clymer SR, MacDermid SM, Weiss HM. Ambiguous absence, ambiguous presence: A qualitative study of military reserve families in wartime. Journal of Family Psychology. 2008; 22(2): 222-30.

[36] Renshaw KD. Deployment experiences and postdeployment PTSD symptoms in National Guard/Reserve service members serving in operations Enduring Freedom and Iraqi Freedom. Journal of Traumatic Stress. 2010; 23(6): 815-8.

[37] Tanielian T, Jaycox LH, Schell TL, Marshall GN, Burnam MA, Eibner C, et al. Invisible Wounds of War: Summary and Recommendations for Addressing Psychological and Cognitive Injuries. Santa Monica, CA: RAND Corporation, 2008, pp. 64.

[38] Wilcox SL, Finney K, Cederbaum JA. Prevalence of Mental Health Problems among Military Populations. In: Moore B, Barnett J, editors. Military Psychologists' Desk Reference. New York, NY: Oxford University Press, 2013, pp. 187-92.

[39] Wilcox SL, Rank MG. Transitioning Through The Deployment Cycle. In: Moore B, Barnett J, editors. Military Psychologists' Desk Reference. New York, NY: Oxford University Press, 2013, pp. 306-11.

[40] Institute of Medicine. Returning Home from Iraq and Afghanistan: Assessment of Readjustment Needs of Veterans, Service Members, and Their Families. Washington, DC: The National Academies Press, 2013.

[41] MacDonald HZ, Proctor SP, Heeren T, Vasterling JJ. Associations of postdeployment PTSD symptoms with predeployment symptoms in Iraq-deployed Army soldiers. Psychological Trauma: Theory, Research, Practice, and Policy. 2013; 5(5): 470-6.

[42] Wright KM, Cabrera OA, Eckford RD, Adler AB, Bliese PD. The impact of predeployment functional impairment on mental health after combat. Psychological Trauma: Theory, Research, Practice, and Policy. 2012; 4(3): 260-9.

[43] MacDonald HZ, Proctor SP, Heeren T, Vasterling JJ. Associations of Postdeployment PTSD Symptoms With Predeployment Symptoms in Iraq-Deployed Army Soldiers. Psychological Trauma: Theory, Research, Practice, and Policy. 2012: No Pagination Specified.

[44] Riggs DS, Byrne CA, Weathers FW, Litz BT. The quality of the intimate relationships of male Vietnam veterans: Problems associated with posttraumatic stress disorder. Journal of Traumatic Stress. 1998; 11(1): 87-101.
[45] Hirsch KA. Sexual dysfunction in male Operation Enduring Freedom/Operation Iraqi Freedom patients with severe posttraumatic stress disorder. Military Medicine. 2009; 174(5): 520-2.

[46] Meis LA, Erbes CR, Polusny MA, Compton JS. Intimate relationships among returning soldiers: The mediating and moderating roles of negative emotionality, PTSD symptoms, and alcohol problems. Journal of Traumatic Stress. 2010; 23: 56472 .

[47] Jordan K. Counselors helping service veterans re-enter their couple relationship after combat and military services: A comprehensive overview. The Family Journal. 2011; 19(3): 263-73.

[48] Aloni R, Katz S. Sexual difficulties after traumatic brain injury and ways to deal with it: Charles $\mathrm{C}$ Thomas Publisher, 2003.

[49] Knox KL, Kemp J, McKeon R, Katz IR. Implementation and Early Utilization of a Suicide Hotline for Veterans. American Journal of Public Health. 2012; 102(S1): S29-S32.

[50] Interian A, Kline A, Callahan L, Losonczy M. Readjustment Stressors and Early Mental Health Treatment Seeking by Returning National Guard Soldiers With PTSD. Psychiatric Services. 2012; 63(9): 855-61.

[51] Hazle M, Wilcox SL, Hassan AM. Helping Veterans And Their Families Fight On! Advances in Social Work. 2012; 13(1): 229-42.

[52] Schell TL, Tanielian T. A Needs Assessment of New York State Veterans: Final Report to the New York State Health Foundation. Santa Monica, CA: RAND Corporation, 2011.

[53] Clemens EV, Milsom AS. Enlisted service members' transition into the civilian world of work: A cognitive information processing approach. The Career Development Quarterly. 2008; 56(3): 246-56.

[54] Hoshmand LT, Hoshmand AL. Support for military families and communities. Journal of Community Psychology. 2007;35(2):171-80.

[55] Werber L, Harrell MC, Varda DM, Hall KC, Becklett MK, Stern S. Deployment Experiences of Guard and Reserve Families: Implications for Support and Retention. Santa Monica, CA: RAND Corporation, 2008.

[56] Kline A, Ciccone DS, Falca-Dodson M, Black CM, Losonczy M. Suicidal ideation among national guard troops deployed to iraq: The association with postdeployment readjustment problems. Journal of Nervous and Mental Disease. 2011; 199(12): 914-20.

[57] Castaneda LW, Harrell MC, Varda DM, Hall KC, Beckett MK, Stern S. Deployment experiences of guard and reserve families. Santa Monica, CA: RAND Corporation, 2008.

[58] Drummet AR, Coleman M, Cable S. Military Families Under Stress: Implications for Family Life Education*. Family Relations. 2003; 52(3): 279-87.

[59] Sahlstein E, Maguire KC, Timmerman L. Contradictions and praxis contextualized by wartime deployment: Wives' perspectives revealed through relational dialectics. Communication Monographs. 2009; 76(4): 421-42.

[60] Lester P, Bursch B. The long war comes home: mitigating risk and promoting resiliency in military children and families. Psychiatric Times. 2011; 28(7): 26-9.

[61] Satcher D, Tepper MS, Thrasher C, Rachel SA. Breaking the Silence: Supporting Intimate Relationships for Our Wounded Troops and Their Partners: A Call to Action. International Journal of Sexual Health. 2012; 24(1): 6-13.

[62] Cameron RP, Mona LR, Syme ML, Cordes CC, Fraley SS, Chen SS, et al. Sexuality among wounded veterans of Op- 
eration Enduring Freedom (OEF), Operation Iraqi Freedom (OIF), and Operation New Dawn (OND): Implications for rehabilitation psychologists. Rehabilitation Psychology. 2011; 56(4): 289.

[63] Kotler M, Cohen H, Aizenberg D, Matar M, Loewenthal U, Kaplan Z, et al. Sexual dysfunction in male posttraumatic stress disorder patients. Psychotherapy and Psychosomatics. 2000; 69: 309-15.

[64] Marshall AD, Panuzio J, Taft CT. Intimate partner violence among military veterans and active duty servicemen. Clinical Psychology Review. 2005; 25(7): 862-76.

[65] McCarroll JE, Fan Z, Newby JH, Ursano RJ. Trends in US Army child maltreatment reports: 1990-2004. Child Abuse
Review. 2008; 17(2): 108-18

[66] Rentz ED, Marshall SW, Loomis D, Casteel C, Martin SL, Gibbs DA. Effect of Deployment on the Occurrence of Child Maltreatment in Military and Nonmilitary Families. American Journal of Epidemiology. 2007; 165(10): 1199-206.

[67] Gibbs DA, Martin SL, Kupper LL, Johnson RE. Child Maltreatment in Enlisted Soldiers' Families During CombatRelated Deployments. JAMA: The Journal Of The American Medical Association. 2007; 298(5): 528-35.

[68] Wilcox SL, Redmond S, Hassan AM. Sexual Functioning in Military Personnel: Preliminary Estimates and Predictors. Journal of Sexual Medicine. 2014; 11(10): 2537-45. 